\title{
Dampak Sosial Perlindungan Hukum Hak Cipta dan Merek di Kepulauan
} Riau

\author{
Widya Devega \\ widya_devega17@yahoo.com ${ }^{1}$ \\ Adji Suradji Muhammad \\ $\underline{\text { suradji@umrah.ac.id }}^{2}$ \\ Ramadhani Setiawan \\ $\underline{\text { ramadhanisetiawan@gmail.com }}{ }^{3}$
1,2,3Program Studi Administrasi Publik, Fakultas Ilmu Sosial dan Ilmu Politik, Universitas Maritim Raja Ali Haji

\begin{abstract}
ABSTRAK
Hak Kekayaan Intelektual (HKI) adalah salah satu peran strategis dalam memajukan kesejahteraan umum Negara. Dengan latar belakang Indonesia sebagai salah satu negara dengan kasus pembajakan HKI terbesar di dunia, maka diharapkan dengan adanya perlindungan hukum tersebut dapat memperbaiki citra Indonesia di mata dunia. Tujuan dari penelitian ini adalah untuk mengetahui Dampak Sosial Perlindungan Hukum Hak Cipta dan Merek di Kepulauan Riau. Metode penelitian adalah kualitatif dengan pendekatan deskriptif. Informan dalam penelitian ini adalah analisis pertimbangan hukum HKI, pencipta, masyarakat/konsumen dan masyarakat yang tidak mendaftarkan hasil karyanya. Dari hasil penelitian ini maka dapat disimpulkan bahwa dampak sosial yang terjadi akan memberikan kepastian hukum bagi para pemegang hak, menumbuh kembangkan kreatifitas, merasa was-was akan adanya pembajakan atas karya yang belum didaftarkan, serta mempersempit ruang gerak para pelaku pelanggaran HKI, dengan begitu produk-produk original akan semakin banyak beredar. Adapun saran dalam penelitian ini adalah Kementerian Hukum dan Hak Asasi Manusia Kantor Wilayah Kepulauan Riau, hendaknya melakukan sosialisasi secara merata demi menyebarluaskan informasi-informasi mengenai HKI. sehingga, masyarakat mengetahui infromasi seperti biaya, prosedur, sanksi dan urgensi dari pendaftaran HKI.
\end{abstract}

Kata kunci: Dampak Sosial, Perlindungan Hukum, Hak Kekayaan Intelektual

\begin{abstract}
Intellectual Property Rights (HKI) is one of strategic roles in advancing general welfare of the State. With Indonesia's background as one of the countries with largest IPR piracy cases in the world, it is hoped that with protection of law it can improve the image of Indonesia in the eyes of the world. The purpose of this study was to find out Social Impact of Copyright and Brand Legal Protection in the Riau Archipelago. The research method is qualitative with a descriptive approach. Informants in this study were an analysis of legal considerations for Intellectual Property Rights(HKI), creators, communities/consumers and public who did not register their work. From results of this study, it can be concluded that social impacts that occur will provide legal certainty for rights holders, develop creativity, feel anxious about the existence of piracy of works that have not been registered, and narrow space for the movement of Intellectual Property Rights (HKI) violators, thus the products original will be circulating. Suggestion in this study is Ministry of Law and Human Rights of the Riau Archipelago Regional Office, which should evenly disseminate information to disseminate information on Intellectual Property Rights (HKI). Thus, public knows information such as costs, procedures, sanctions and the urgency of registering Intellectual Property Rights(HKI).
\end{abstract}

Keywords: Social Impact, Legal Protection, Intellectual Property Rights 


\section{PENDAHULUAN}

Penelitian ini memaparkan tentang dampak sosial perlindungan hukum hak cipta dan merek di Kepulauan Riau. Dalam kebijakan publik, evaluasi kebijakan merupakan tahap akhir setelah implementasi kebijakan, dengan dilakukannya evaluasi, maka akan diketahui dampak dari sebuah kebijakan. Perlindungan hukum menjadi penting karena bertujuan untuk pelaksanaan dan pemanfaatan dari karya yang telah didaftarkan seperti membuat, menggunakan, menjual, mengimpor, menyewakan ataupun yang lainnya. Sehingga serangkaian langkah-langkah kebijakan yang diformulasikan untuk mempromosikan dan manfasilitasi kreasi, perlindungan, manajemen, dan pemanfaat kekayaan intelektual secara efektif, menjadi sarana strategis untuk mendukung pembangunan ekonomi (Taufik $\mathrm{H}$. Simatupang, 2017:206).

Sejalan dengan perkembangan budaya, seni, ilmu pengetahuan, kreatifitas, dan sumber daya manusia di Indonesia yang begitu tinggi merupakan suatu potensi besar dalam hal kekayaan intelektual (Nur Mukarromah, 2012:3). Namun masih banyak ditemukan plagiat dan pembajakan atas suatu karya dengan harga yang lebih murah, sehingga disekitar kita tidak sulit mencari barang-barang bajakan atau merek-merek yang ditiru. Hal lain yang menjadi perhatian khusus bagi semua warga negara Indonesia adalah kesenian dan kebudayaan yang di miliki Indonesia dengan mudahnya dapat diklaim sebagai domain pihak lain yang lebih dulu mempublikasi dan mendaftarkan karya tersebut. Terlebih lagi, masyarakat adat sebagai pemilik kolektif pengetahuan tradisional tersebut tidak memperoleh keuntungan yang adil atas kemanfaatannya, menurut Abdul Atsar, (2017:287). Apabila terbukti bersalah maka para pelanggar tersebut harus diproses secara hukum dan dapat dijatuhkan hukuman sesuai peraturan yang 
berlaku dengan hukuman yang bersifat pidana ataupun perdata.

\section{LANDASAN TEORI}

A. Dampak Sosial

Perlu diketahui beberapa dimensi

dampak dari kebijakan menurut Leo

Agustino (2014:191), yaitu:

1. Pengaruhnya pada persoalan masyarakat yang berhubungan dan melibatkan masyarakat. Pertamatama harus didefiniskan siapa yang akan terkena pengaruh kebijakan. Kedua, perlu kiranya ditentukan dampak dan tujuan dari kebijakan yang dimaksud.

2. Kebijakan dapat mempunyai dampak pada situasi dan kelompok lain. Hal tersebut memiliki dampak eksternalitas yang negative walau disisi lain ada pula dampak eksternal positifnya.

3. Kebijakan dapat mempunyai pengaruh dimasa mendatang seperti pengaruhnya pada kondisi saat ini.perlu dipikirkan apakah kebijakan tersebut memiliki pengaruh jangka pendek, jangka menengah atau jangka panjang.

4. Kebijakan dapat mempunyai dampak yang tidak langsung yang merupakan pengalaman dari suatu komunitas atau beberapa anggota diantaranya. Tentu saja sulit untuk mengukur keuntungan yang tidak langsung dari kebijakan publik untuk masyarakat tertentu. Misalnya kebijakan mengenai HKI telah mendorong kepada aktivitas yang kreatif dan inovatif, dan itu merupakan sumbangan pada pertumbuhan ekonomi dan perkembangan sosial masyarakat.
B. Perlindungan Hukum Hak Kekayaan Intelektual

perlu dipahami unsur-unsur penting

di dalam perlindungan $\mathrm{HKI}$, menurut

Abdul Kadir Muhammad (Heri

Firmansyah, 2011:11). Sebagai berikut:

1. Larangan Undang-undang

Perbuatan yang dilakukan oleh seseorang pengguna HKI dilarang dan diancam dengan hukuman oleh undang-undang;

2. Izin (lisensi)

Pengguna HKI dilakukan tanpa persetujuan dari pemilik atau pemegang hak terdaftar;

3. Pembatasan undang-undang

Pengguna HKI melampaui batas ketentuan yang telah ditetapkan oleh undang-undang; dan

4. Jangka waktu

Penggunaan HKI dilakukan dalam jangka waktu perlindungan yang telah ditetapkan undang-undang atau perjanjian tertulis atau lisensi.

Perlindungan hukum HKI bukan merupakan tujuan akhir dari HKI itu sendiri karena pada dasarnya tujuan dibuatnya aturan HKI adalah dampak sosial dari perlindungan hukum HKI itu sendiri. Dampak sosial menurut Sudharto (Wawan Kurniawan, 2015:10) merupakan perubahan yang terjadi pada manusia dan masyarakat yang diakibatkan oleh aktifitas pembangunan. Dampak sosial muncul 
ketika terdapat aktifitas seperti proyek, program atau kebijaksanaan yang diterapkan pada suatu masyarakat. Hal tersebut dapat mempengaruhi keseimbangan pada suatu sistem masyarakat, pengaruh tersebut bisa positif maupun negatif.

\section{Hak Kekayaan Intelektual}

Hak Kekayaan Intelektual (HKI), dengan demikian, bertujuan untuk meningkatkan perlindungan hukum di bidang hak cipta dan merek dalam kaitannya dengan perdagangan barang dan jasa serta memperketat aturan mengenai barang-barang palsu, sehingga apabila dilanggar maka akan mendapatkan sanksi berupa pidana penjara dan membayarkan denda. Menurut Sulasno (2015:353) mengatakan bahwa:

"Perlindungan Hak Kekayaan Intelektual menjadi penting karena dapat melindungi dan menegakkan hukum Hak Kekayaan Intelektual (HKI) guna mendorong timbulnya inovasi, pengalihan serta penyebaran ilmu pengetahuan, teknologi, seni dan sastra, sehingga bermuara pada kesejahteraan sosial ekonomi masyarakat".

Grafik 1 Jumlah Pendaftaran Hak Kekayaan Intelektual di Kepulauan Riau

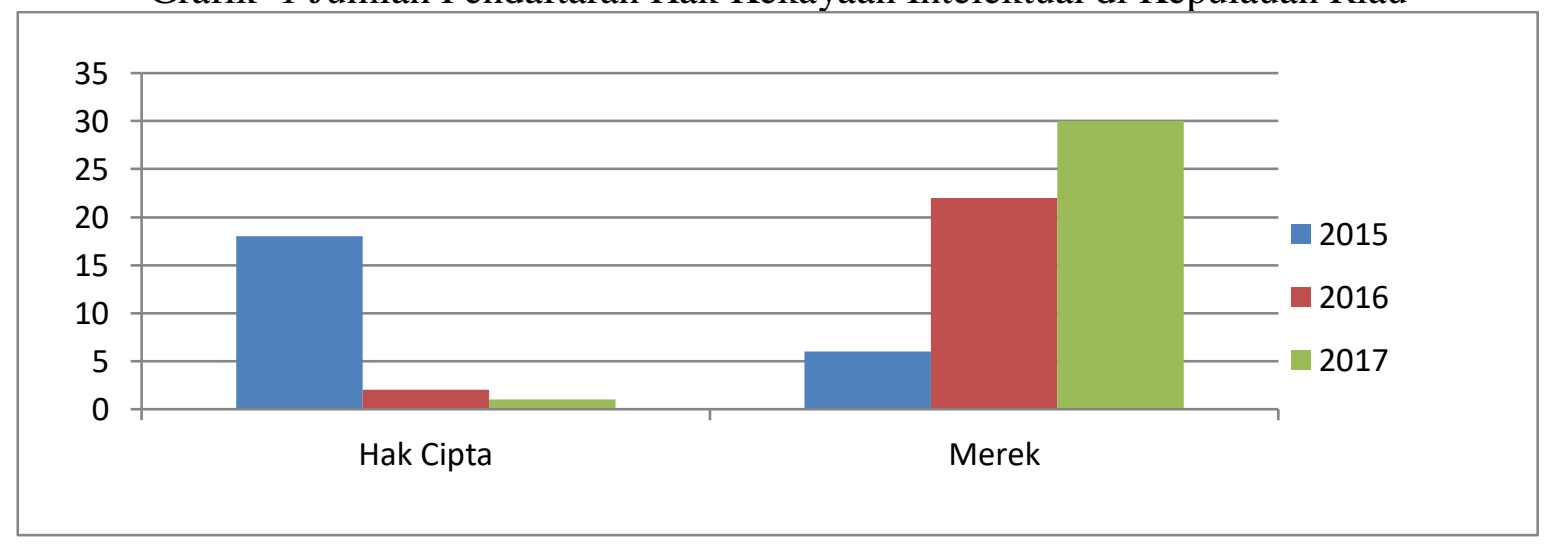

Sumber: Aplikasi Hak Kekayaan Intelektual Kementerian Hukum dan Hak Asasi Manusia Kantor Wilayah Kepulauan Riau

Berdasarkan grafik di atas, jumlah pendaftaran hak cipta mengalami penuruan dan merek mengalami peningkatan pada tahun 2017 di Kepulauan Riau. Kondisi ini menjadi salah satu alasan peneliti untuk melakukan penelitian lebih jauh terkait kesuksesan HKI. Kesuksesan HKI juga tidak terlepas dari peran masyarakat. Dimana masyarakat turut andil dengan 
mendaftarkan hasil karya intelektualnya dan memperoleh segala manfaat dengan mendaftarkan karyanya dan masyarakat yangdapat mensosialisasikan HKI denan tidak memberi barang-barang bajakan.

Masyarakat Indonesia masih dalam masa transisi industrial yang digambarkan sebagai masyarakat yang mengalami perubahan dari masyarakat agraris (komunal tradisional) menjadi masyarakat yang modern. Sehingga, pengetahuan dan kesadaran masyarakat tentang HKI masih rendah. Hal ini dapat dilihat dari masih sedikitnya masyarakat pencipta yang mendaftarkan hasil karyanya untuk mendapatkan perlindungan hukum terhadap pelanggaran hak cipta, hal ini diungkapkan dari hasil penelitian (Riska Hanifah Arma, 2016:67).

\section{METODE PENELITIAN}

Jenis penelitian yang digunakan adalah kualitatif dengan pendekatan deskriptif, Metode penelitian ini dipilih yaitu bertujuan untuk menggambarkan dan mengungkapkan dampak sosial perlindungan hukum hak cipta dan merek di Kepulauan Riau. Lokasi penelitian berada di Tanjungpinang, tepatnya di Kementerian Hukum dan Hak Asasi Manusia Kantor Wilayah Kepulauan Riau yang merupakan instansi yang berhak menerima permohonan dan memroses permohonan segala jenis kekayaan intelektual.

Jenis data yang digunakan dalam penelitian ini meliputi data primer dan data sekunder. Data primer diperoleh melalui wawancara pada informan dan lokus yang telah ditentukan, semua hasil yang diperoleh ditabulasi dan dianalisis secara deskriptif dalam bentuk lisan maupun tulisan. Sedangkan data sekunder diperoleh melalui penelusuran berbagai pustaka seperti Undang-undang Republik Indonesia, peraturan-peraturan yang terkait, buku-buku, tulisan-tulisan penelitian, studi kasus, ataupun artikel dan jurnal yang diterbitkan berhubungan dengan penelitian ini dan Kementerian Hukum dan Hak Asasi Manusia Kantor 
Wilayah Kepulauan Riau dalam bentuk dokumen dan data.

Informan dalam penelitian ini terdiri dari Analisis Pertimbangan Hukum Kementerian Hukum dan Hak Asasi Manusia Kantor Wilayah Kepulauan Riau (1 orang), para pemegang hak yang sudah mendaftarkan hasil karyanya (7 orang), masyarakat umum atau konsumen (5 orang), dan masyarakat yang tidak mendaftarkan hasil karyanya (6 orang). Teknik pengambilan informasi yang digunakan adalah purposive sampling yaitu dengan mengambil subjek penelitian yang memenuhi kriteria. Dimana kriteria tersebut dibuat oleh peneliti sendiri. Kriteria yang menjadi sampel dalam penelitian ini adalah:

a. Para informan yang telah disebutkan di atas,

b. Informan yang memiliki otoritas, c. Informan yang bersedia diwawancarai.

Dalam teknik pengumpulan data, triangulasi diartikan sebagai teknik pengumpulan data yang bersifat menggabungkan dari berbagai teknik pengumpulan data dan sumber data yang telah ada (Sugiyono, 2011:241). Teknik pengumpulan data yang dilakukan dalam penelitian ini melalui metode triangulasi yaitu terdiri dari observasi, wawancara dan dokumentasi.

\section{HASIL DAN PEMBAHASAN}

\section{A. Analisis Pengaruh Perlindungan Hukum Hak Cipta dan Merek bagi Kepentingan Umum}

Pengaruhnya pada persoalan masyarakat yang berhubungan dan melibatkan masyarakat. Dalam hal ini kebijakan yang dibuat sudah diformulasikan dengan baik, dengan memperhatikan kebutuhan yang ada di masyarakat, Leo Agustino (2014:191). Maka, dengan adanya perlindungan hukum Hak Kekayaan Intelektual khususnya pada jenis hak cipta dan merek akan berdampak kepada:

1. Masyarakat yang telah mendaftarkan hasil karyanya, agar memperoleh kepastian hukum atas karyanya. 
2. Masyarakat yang belum mendaftarkan hasil karyanya, agar termotivasi untuk melindungi karyanya.

3. Pembajak, agar pembajak merasa perlu berpikir ulang untuk melakukan pelanggaran hak cipta dan merek, dikarenakan sanksi yang begitu besar dan meminimalisir barang bajakan yang beredar.

4. Masyarakat umum selaku konsumen, agar masyarakat umum menjadi cerdas dalam memilih produk yang akan digunakan.

B. Dampak Positif dan Dampak Negatif dengan Adanya Perlindungan Hukum Hak Cipta dan Merek

Kebijakan dapat mempunyai dampak pada situasi dan kelompok lain. Hal tersebut memiliki dampak eksternalitas yang negatif walau disisi lain ada pula dampak eksternal positifnya. Bagi masyarakat yang telah mendaftarkan hasil karyanya dan masyarakat umum selaku konsumen tentu mendapatkan dampak positif dari adanya perlindungan hukum hak cipta dan merek. Sebaliknya, bagi masyarakat yang belum mendaftarkan hasil karyanya dan para pembajak akan mendapatkan dampak negatifnya.

Berikut adalah dampak yang diterima oleh masyarakat yang sudah mendaftarkan hasil karyanya dan para konsumen, sebagai berikut:

1. Menjamin kepastian hukum sebagai pemegang hak cipta atau sebagai pemegang merek, yang artinya sudah dijamin dan sudah mendapatkan perlindungan dari negera.

2. Menambah kualitas diri secara pribadi dan adanya pengakuan dari pemerintah terhadap hasil karya tersebut.

3. Karya tersebut punya nama di masyarakat.

4. Dapat melebarkan sayap karya mereka keluar daerah ataupun ke luar negeri.

5. Sebagian masyarakat yang telah mendaftarkan hasil karyanya berpendapat belum ada dampak 
ekonominya karena pada dasarnya Kepulauan Riau dianggap sebagai daerah yang belum memiliki kotakota besar yang bisa bersaing secara ekonomi dengan kota-kota besar selain Kepulauan Riau. Di Kepulauan Riau ini belum ada kasus pembajakan yang teraftar di Kemenkumham karena masyarakat memilih untuk menyelesaikannya secara musyawarah, jikalau ada masyarakat memilih tidak melaporkan karena beranggapan akan mengeluarkan biaya yang tidak sedikit. Dan yang menjadi perhatian masyarakat bukanlah karya tersebut sudah terdaftar atau belum, melainkan produk halal, SITU, dan ada sebagian karya cipta yang tidak diperjual belikan. Dan juga konsep ekonomi tergantung dengan upaya seseorang sejauh mana orang tersebut berupaya dan berkomitmen. Untuk dalam beberapa keadaan mengapa dampak ekonomi belum begitu dirasakan bagi pencipta karena diera digital, karya-karya cipta seperti lagu sudah jarang diperjual belikan ditoko-toko.

Selanjutnya adalah dampak yang diterima oleh masyarakat yang belum mendaftarkan hasil karyanya dan para pembajak, sebagai berikut:

1. Banyak yang mengatas namakan merek yang belum terdaftar.

2. Kebijakan tentang perlindungan hak cipta dan merek belum berjalan dengan baik karena sosialisasi yang belum mampu meningkatkan kesadaran masyarakat, serta banyaknya produk-produk bajakan yang tersebar di Kepulauan Riau.

3. Bagi para pembajak tentu akan mendapatkan sanksi pidana sesuai dengan Undang-undang Hak Cipta dan Undang-undang Merek sehingga akan mempersempit ruang gerak pembajak dan tidak bisa seenaknya mencuri, mengambil atau menyamakan karya orang lain. 
C. Dampak Jangka Panjang dengan Diterapkannya Perlindungan Hukum Hak Cipta dan Merek di Kepulauan Riau

Kebijakan dapat mempunyai pengaruh dimasa mendatang seperti pengaruhnya pada kondisi saat ini perlu dipikirkan apakah kebijakan tersebut memiliki pengaruh jangka pendek, jangka menengah atau jangka panjang. Maka dari itu, dari adanya perlindungan hukum hak cipta dan merek di Kepulauan Riau memiliki dampak panjang dan juga diharapkan akan dapat direalisasikan, yakni sebagai berikut:

1. Agar menumbuh-kembangkan

kreativitas bagi masyarakat lainnya.
Masyarakat menjadi termotivasi untuk mendaftarkan hasil karyanya dan bagi masyarakat yang belum memiliki karya termotivasi untuk menciptakan ide-ide baru, penelitian-penelitian ataupun karyakarya lebih lanjut.

2. Perlindungan karya yang sudah terdaftar akan dilindungi sampai pemilik meninggal dunia dan ditambah 70 tahun setelah pemilik meninggal dunia untuk jenis hak cipta dan 10 Tahun untuk jenis merek.

Tabel 1 Jumlah Pendaftaran Hak Kekayaan Intelektual di Kepulauan Riau

\begin{tabular}{cccccc}
\hline No & $\begin{array}{c}\text { Jenis-Jenis } \\
\text { HKI }\end{array}$ & 2015 & 2016 & 2017 & Jumlah \\
\hline 1. & Hak Cipta & 18 & 2 & 1 & 21 \\
\hline 2. & Merek & 6 & 22 & 30 & 58 \\
\hline
\end{tabular}

Sumber: Aplikasi Hak Kekayaan Intelektual Kementerian Hukum dan Hak Asasi Manusia Kantor Wilayah Kepulauan Riau

Berdasarkan tabel di atas, regulator dan fasilitator. Masyarakat yang pendaftaran hak cipta mengalami sudah mendaftarkan hasil karyanya yang penurunan sedangkan pendaftaran merek turut andil dalam menciptakan karya-karya mengalami peningkatan. Kesuksesan Hak untuk mengembangkan kreatifitas, Kekayaan Intelektual tidak terlepas dari pengetahuan, budaya, industri dan lainnya. berbagai aktor, yaitu pemerintah selaku Juga, diperlukan peran masyarakat umum 
yang berperan mensosialisasikan Hak

Kekayaan Intelektual dengan

menggunakan barang-barang dengan

produk original. Namun, pada kenyataannya masyarakat tidak begitu memperdulikan brand dari suatu karya. Khususnya di Kepulauan Riau trend merek sedang meningkat dikarenakan masyarakat yang telah memiliki karyanya berlombalomba untuk mendaftarkan merek tersebut demi melindungi mereknya dari plagiasi atau pencegahan pemanfaatan ekonomi oleh pihak lain. Hal lain yang menyebabkan pendaftaran Hak Kekayaan Intelektual khususnya di Kepulauan Riau menurun juga dilandasi tidak adanya pengaruh ekonomi yang dirasakan dengan adanya menciptakan suatu karya. Dan juga Kemenkumham kanwil Kepri bukanlah tempat satu-satunya untuk bisa mendaftarkan hasil karyanya. Masyarakat bisa mendaftarkan hasil karyanya melalui
Dirjen HKI Pusat, Centra KI, ataupun konsultan KI (Untuk Wilayah Kepulauan Riau belum tersedia).

3. Memperbaiki nama dan citra Indonesia di hadapan Internasional yang menjadi negara dengan jumlah pembajak HKI terbesar.

D. Implikasi Perlindungan Hukum Hak Cipta dan Merek Secara Tidak Langsung

Kebijakan dapat mempunyai dampak yang tidak langsung yang merupakan pengalaman dari suatu komunitas atau beberapa anggota diantaranya. Tentu saja sulit untuk mengukur keuntungan yang tidak langsung dari kebijakan publik untuk masyarakat tertentu. Misalnya kebijakan mengenai HKI telah mendorong kepada aktivitas yang kreatif dan inovatif, dan itu merupakan sumbangan pada pertumbuhan ekonomi dan perkembangan sosial masyarakat. 
Grafik 2 Indikator dalam menentukan dampak dari adanya perlindungan Hukum Hak Cipta dan merek di Kepulauan Riau

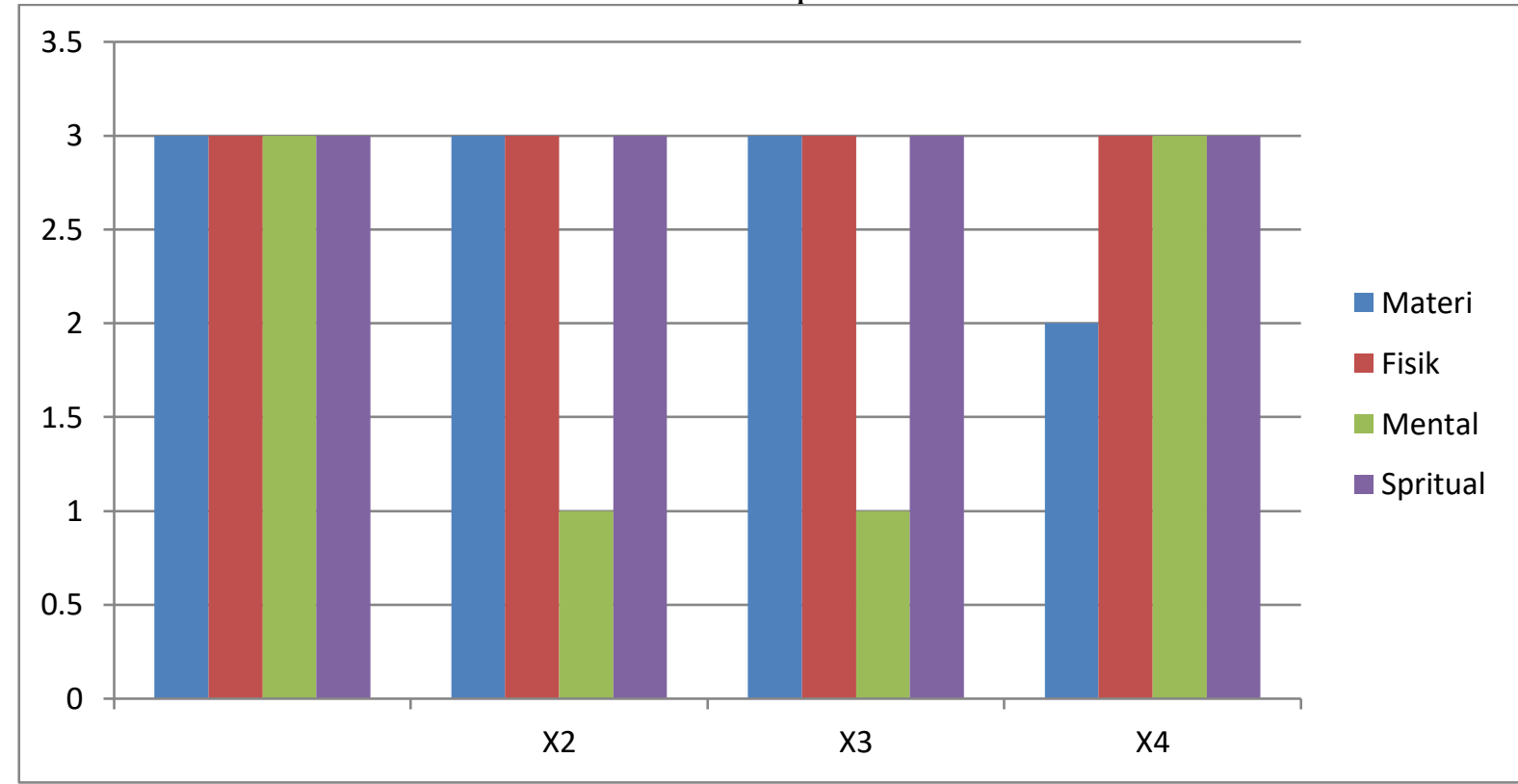

Dari grafik 2 di atas Dampak Sosial dari adanya Perlindungan Hukum Hak Cipta dan merek di Kepulauan Riau terdiri atas 4 Jenis yaitu dari segi materi (kualitas rumah, bahan pangan, dll), segi fisik (ktubuh, lingkungan alam, dll), Segi mental (fasilitas pendidikan, lingkungan budaya, dll), dan segi spiritual (moral, etika, dll) yang dapat dirasakan oleh berbagai pihak. Mulai dari pencipta (X1), Masyarakat yang tidak mendaftarkan hasil karyanya (X2), para pihak yang melakukan pelanggaran Hak Kekayaan Intelektual (X3) dan masyarakat umum selaku konsumen (X4).
Dilihat dari segi materi seperti kualitas rumah, bahan pagan, dll. Dengan adanya perlindungan Hukum Hak Cipta dan Merek di Kepulauan Riau tidak membedakan pendapatan secara ekonomi, karena Kepulauan Riau yang terdiri dari berbagai macam pulau sehingga sulit mengungkapkan adanya kasus pembajakan, jikalau ada, masyarakat lebih memilih untuk menyelesaikannya secara musyawarah. Dikarenakan adanya beberapa faktor, seperti kurangnya pengetahuan masyarakat untuk melaporkan kasus pembajakan, biaya yang dirasa begitu mahal, kurang percaya diri 
dengan perlindungan hukum yang

diberikan untuk mengklaim dari

kemenangan akan kasus yang berjalan.

Dengan adanya perlindungan hak cipta dan merek juga tidak berpengaruh kepada peningkatan ekonomi seseorang karena peningkatan ekonomi bukan dilihat dari adanya perlindungan hukum namun seberapa komitmennya seseorang dalam mengembangkan usahanya juga khususnya di Kepulauan Riau belum adanya persaingan usaha yang sengit, sehingga para pengusaha berjalan dikoridornya masing-masing. Namun, khususnya bagi konsumen, Masyarakat berpenghasilan tinggi akan membeli produk yang terdaftar begitu pun sebaliknya. Masyarakat pada umumnya juga tidak menanyakan apakah suatu produk sudah terdaftar atau belum.

Dilihat dari segi fisik (kesehatan tubuh, lingkungan alam, dll). tidak ada perbedaan yang ditunjukkan dari perlindungan hukum. Berdasarkan hasil pengamatan yang dilakukan secara langsung di lapangan, kesehatan para informan tidak ada yang berbeda dan cenderung sama dengan tubuh yang tampak sehat dengan lingkungan hidup yang aman dan memadai. Sedangkan dilihat dari Segi spiritual (moral, etika, dll) juga Moral dan etika yang ditunjukan selama proses wawancara telihat baik dan menunjukkan perilaku dan perbuatan yang cenderung sama dengaan ramah, terbuka, dan bersahabat.

Dilihat dari Segi mental (fasilitas pendidikan, lingkungan budaya, dll) masyarakat dalam ligkungan budaya yang sama, cenderung menjalankan hidup bersosialisasi yang sama dengan adanya sikap tidak peduli tentang pentingnya perlindungan hukum bagi Hak Kekayaan Intelektual. maka dengan begitu ada perbedaan yang dirasakan dengan adanya perlindungan hukum hak cipta dan merek di Kepulauan Riau. Pertama, pencipta Merasakan rasa aman dan nyaman dengan adanya kekuatan hukum bagi karyanya dan menciptakan produk yang original. Kedua, masyarakat yang tidak mendaftarkan 
karyanya merasa was-was dan mengalah apabila ada perusahaan lebih besar yang melakukan plagiasi walaupun sama-sama belum mendaftar hasil karyanya.

Ketiga, menimbulkan rasa jera kepada pembajak jika masyarakat semakin cerdas dan tidak mau membeli barangbarang bajakan. Dan yang ke empat, tentunya masyarakat umum merasa lebih memuaskan, memiliki kebanggaan dan menyenangkan karena menggunakan produk original sehingga kepercayaan masyarakat meningkat dengan produk.

\section{PENUTUP}

Dari hasil penelitian di lapangan maka dapat diambil kesimpulan bahwa Dampak Sosial Perlindungan Hukum Hak Cipta dan Merek di Kepulauan Riau adalah sebagai berikut: (1) Dampak sosial bagi masyarakat yang telah mendaftarkan hasil karyanya mendapatkan perlindungan hukum hak cipta dan merek dan dengan percaya diri akan mampu mengembangkan usaha atau karya tersebut, (2) Dampak sosial bagi masyarakat yang belum mendaftarkan hasil karyanya merasa waswas akan ada karya-karya yang mengatas namakan identitas seperti apa yang mereka miliki, (3) Dampak sosial bagi pembajak akan meminimalisir ruang gerak mereka untuk memproduksi barang-barang bajakan, sehingga produk-produk tersebut semakin sedikit jumlahnya, (4) Dampak sosial bagi masyarakat umum selaku konsumen maka akan mendapatkan pencerahan untuk memilih barang-barang yang sudah diakui Negara, (5) Dampak sosial di masa yang akan datang akan menumbuh kembangkan kreatifitas anak bangsa sehingga mampu menciptakan karya-karya yang dapat mengembangkan negara serta memperbaiki citra negara dan melakukan persaingan dengan taraf internasional, (6) Kurang adanya sosialisasi yang merata untuk menyebarluaskan informasi mengenai pentingnya pendaftaran Hak Kekayaan Intektual dan (7) Kasus pembajakan yang banyak diselesaikan dengan cara musyawarah karena masyarakat berpikir 
dua kali untuk melaporkan ke pihak yang berwajib karena terkendala masalah biaya, pihak pengacara dan prosedur.

Dari kesimpulan di atas, maka dapat dipaparkan saran untuk mengatasi kekurangan tersebut adalah (1) kesuksesan Hak Kekayaan Intelektual tidak terlepas dari peran masyarakat. Diharapkan masyarakat ikut berpartipasi dalam hal ini seperti membeli barang-barang original, (2) Pemerintah dalam hal ini Kemenerian Hak Asasi Manusia Kanwil Kepri Subbidang Administrasi Hukum Umum dan HKI, hendaknya melakukan sosialisasi dan menfasilitasi secara merata untuk menyebarluaskan informasi mengenai HKI, (3) Menciptakan lembaga yang bersinergi dalam melakukan pembelaan hukum bagi masyarakat yang telah mendaftarkan karyanya dan

Pemerintah lebih gencar memberikan peringatan bagi para penjual barang bajakan.

\section{DAFTAR PUSTAKA}

Agustino, Leo. 2014. Dasar-dasar Kebijakan Publik. Bandung:Alfabeta
Arma, R. H. (2016). Perlindungan Hukum Hak Cipta dari Kejahatan Pembajakan Software Komputer Menurut Trips Agreements dan Pelaksanaannya di Indonesia, 2017.

Atsar, A. (2017). Perlindungan Hukum Terhadap Pengetahuan dan Ekspresi Budaya Tradisional untuk Meningkatkan Kesejateraan Masyarakat Ditinjau dari Undangundang No. 28 Tahun 2014 Tentang Hak Cipta, Volume 13.

Firmansyah, Hery. 2011. Perlindungan Hukum Terhadap Merek. Jakarta Selatan: PT Buku Seru

Kementerian Hukum dan Hak Asasi Manusia Kantor Wilayah Kepulauan Riau. (2017). Aplikasi Hak Kekayaan Intelektual.

Kurniawan, W. (2015). Dampak sosial ekonomi pembangunan pariwisata umbul sidomukti kecamatan bandungan kabupaten semarang.

Mukarromah, N. (2012). Evaluasi atas Implementasi Kebijakan Perlindungan Hak Cipta Bidang Musik dan Lagu pada Direktorat Jenderal Hak Kekayaan Intelektual (HKI) Kementerian Hukum dan HAM, 2017.

Simatupang, T. H. (2017). Sistem Hukum Perlindungan Kekayaan Intelektual dalam Rangka Meningkatkan Kesejahteraan Masyarakat, p-ISSN 141.

Sugiyono. 2011. Metode Penelitian Kualitatif. Bandung: Alpabeta

Sulasno. (2015). Lisensi hak kekayaan intelektual (hki) dalam perspektif hukum perjanjian di indonesia. 